\title{
Effect of intramuscular vitamin $A$ injection on plasma levels of vitamin $A$ and retinol-binding protein in malnourished children
}

\author{
BY VINODINI REDDY AND M. MOHANRAM \\ National Institute of Nutrition, Indian Council of Medical Research, Jamai-Osmania, \\ Hyderabad 500007, AP, India
}

(Received 23 April 1980 - Accepted 25 July 1980)

\begin{abstract}
1. Serum levels of retinol-binding protein (RBP), total vitamin A and retinyl ester were measured in twenty-four malnourished children with corneal lesions and nine normal children.

2. Initially, the RBP and vitamin A levels were significantly lower in malnourished children than in normal children.

3. After intramuscular injection of $30000 \mu \mathrm{g}$ of aqueous vitamin A, serum levels of total vitamin A were increased significantly at $24 \mathrm{~h}$ and tended to fall within $5 \mathrm{~d}$ of treatment in both groups.

4. Before treatment, retinyl ester accounted for less than $10 \%$ of the vitamin in circulation. After vitamin A injection, it increased to $30 \%$, a level much lower than that reported in patients with hypervitaminosis $\mathrm{A}$.

5. There was no significant difference between the two groups of children and none of them showed clinical signs of toxicity. These observations indicate that administration of massive doses of vitamin $A$ over a short period will not produce toxic effects even in malnourished children.
\end{abstract}

Excessive intake of vitamin $A$ is known to produce toxic manifestations in animals and man (Wolbach \& Bessey, 1942; Josephs, 1944; Rodahl, 1949; Muenter et al. 1971; Korner \& Vollm, 1975). Hypervitaminosis A has been shown to be associated with increased concentration of total vitamin A in circulation, particularly retinyl ester which is not bound to the retinol-binding protein (RBP) (Mallia et al. 1975; Smith \& Goodman, 1976). Massive doses of vitamin A are now being increasingly used in developing countries for both treatment and prevention of xerophthalmia in children (WHO, 1976; Reddy, 1978). However, concern has been expressed over the safe use of such large doses of the vitamin, since the capacity of the liver to hold the absorbed retinol to the protein is limited in protein-energy malnutrition (PEM). A study was therefore undertaken in malnourished children to determine the effect of massive doses of vitamin $\mathbf{A}$ on retinol transport, particularly the ester form of the vitamin in circulation.

\section{SUBJECTS AND METHODS}

Twenty-four children suffering from severe PEM (marasmic kwashiorkor) and who had conjunctival and corneal xerosis were investigated. Six children had ulceration of the cornea as well. Their ages ranged from 1 to 4 years. Sixteen of these children were treated with a single intramuscular injection of $30000 \mu \mathrm{g}$ water-miscible vitamin A palmitate (Aquesol, Roche Products, Ltd), while the other eight received daily injections of the same dose for three consecutive days. In addition, they were given a diet which provided $4 \mathrm{~g} / \mathrm{kg}$ protein and $840 \mathrm{~kJ} / \mathrm{kg}$ for $3-4$ weeks.

Nine normal children of the same age-group were also studied for comparison. They received a single injection of vitamin $\mathbf{A}$. Blood samples were obtained from all the subjects initially and again on the second and fifth day after vitamin $\mathbf{A}$ injections were given. Free retinol and retinyl ester in serum were separated using deactivated alumina (Vahlquist, 1974) and vitamin A activity determined by a microfluorometric method (Selvaraj \& Susheela, 1970). Serum RBP was measured by immunodiffusion technique (Mancini et al. 1965) and serum albumin by the dye method (Doumas et al. 1971). 
Table 1. Serum retinol-binding protein $(R B P)$ and vitamin $A$ levels in normal and malnourished children

(Mean values with their standard errors)

\begin{tabular}{lcccc}
\hline \hline Group & $\begin{array}{c}\text { No. of } \\
\text { subjects }\end{array}$ & Albumin $(\mathrm{g} / \mathrm{l})$ & $\mathrm{RBP}(\mu \mathrm{g} / \mathrm{ml})$ & $\begin{array}{c}\text { Vitamin A } \\
(\mu \mathrm{g} / \mathrm{l})\end{array}$ \\
\hline $\begin{array}{l}\text { Normal children } \\
\begin{array}{l}\text { Malnourished } \\
\text { children }\end{array}\end{array}$ & 9 & $32 \pm 0.8$ & $33.4 \pm 2.26$ & $287 \pm 18 \cdot 8$ \\
\hline \hline
\end{tabular}

* $P<0.001$ as compared to normal.

Table 2. Effect of a single dose of vitamin $A^{*}$ on serum levels of the vitamin in normal and malnourished children

(Mean values with their standard errors; no. of children in parentheses)

\begin{tabular}{|c|c|c|c|c|c|c|c|}
\hline \multirow[b]{3}{*}{ Group } & \multirow{3}{*}{$\begin{array}{c}\text { Period } \\
\text { after } \\
\text { injection (d) }\end{array}$} & \multirow{2}{*}{\multicolumn{2}{|c|}{$\begin{array}{c}\text { Total vitamin } \mathbf{A} \\
(\mu \mathrm{g} / 1)\end{array}$}} & \multicolumn{4}{|c|}{ Retinyl ester } \\
\hline & & & & \multicolumn{2}{|c|}{$\mu \mathrm{g} / 1$} & \multicolumn{2}{|c|}{$\%$ vitamin $\mathbf{A}$} \\
\hline & & Mean & $\mathbf{S E}$ & Mean & $\mathbf{S E}$ & Mean & $\mathbf{S E}$ \\
\hline $\begin{array}{l}\text { Normal } \\
\text { children (9) }\end{array}$ & $\begin{array}{l}0 \\
2 \\
5\end{array}$ & $\begin{array}{r}277 \\
1526 \\
340\end{array}$ & $\begin{array}{r}17.6 \\
180.2 \\
27.7\end{array}$ & $\begin{array}{r}32 \\
408 \\
74\end{array}$ & $\begin{array}{l}12 \cdot 8 \\
42 \cdot 9 \\
11 \cdot 1\end{array}$ & $\begin{array}{r}9 \cdot 6 \\
34 \cdot 4 \\
21 \cdot 4\end{array}$ & $\begin{array}{l}3.84 \\
3.48 \\
3 \cdot 22\end{array}$ \\
\hline $\begin{array}{l}\text { Malnourished } \\
\text { children (16) }\end{array}$ & $\begin{array}{l}0 \\
2 \\
5\end{array}$ & $\begin{array}{r}80 \\
2154 \\
534\end{array}$ & $\begin{array}{r}12 \cdot 0 \\
360 \cdot 9 \\
61 \cdot 1\end{array}$ & $\begin{array}{l}642 \\
143\end{array}$ & $\begin{array}{r}178 \cdot 8 \\
30 \cdot 3\end{array}$ & $\begin{array}{l}30 \cdot 2 \\
23 \cdot 2\end{array}$ & $\begin{array}{l}3.53 \\
3.39\end{array}$ \\
\hline
\end{tabular}

ND, not detectable.

* $30000 \mu \mathrm{g}$ aqueous vitamin A injection.

Statistical analyses were carried out using Student's $t$ test for comparison of the values of normal and malnourished children, and paired $t$ test for testing the effect of vitamin $\mathbf{A}$ injections.

An informed consent was obtained from parents of all the children investigated. Administration of massive doses of vitamin A to normal children is an accepted prophylactic measure followed in India.

\section{RESULTS}

All children with eye signs showed clinical improvement following vitamin A administration. In those who had xerosis, the lesions cleared up completely and vision was restored to normal within a few days. But those who had corneal ulceration developed opacities and retained only partial vision. There was no difference in the clinical response to a single dose or three doses of vitamin therapy. None of them developed clinical signs of toxicity.

Initially serum albumin, vitamin A and RBP levels were significantly lower in malnourished children than in normal subjects (Table 1). After a single injection of vitamin $\mathbf{A}$, serum vitamin A levels increased significantly on the second day and tended to fall thereafter. The increase was slightly higher in malnourished than in normal children, but the difference was statistically not significant (Table 2). In children who received three doses of the vitamin the response was similar, and serum levels of vitamin A returned to normal within $5 \mathrm{~d}$ after the last dose (Table 3). 
Table 3. Effect of three doses of vitamin $A^{*}$ on serum levels of the vitamin in malnourished children

(Mean values with their standard errors for eight children)

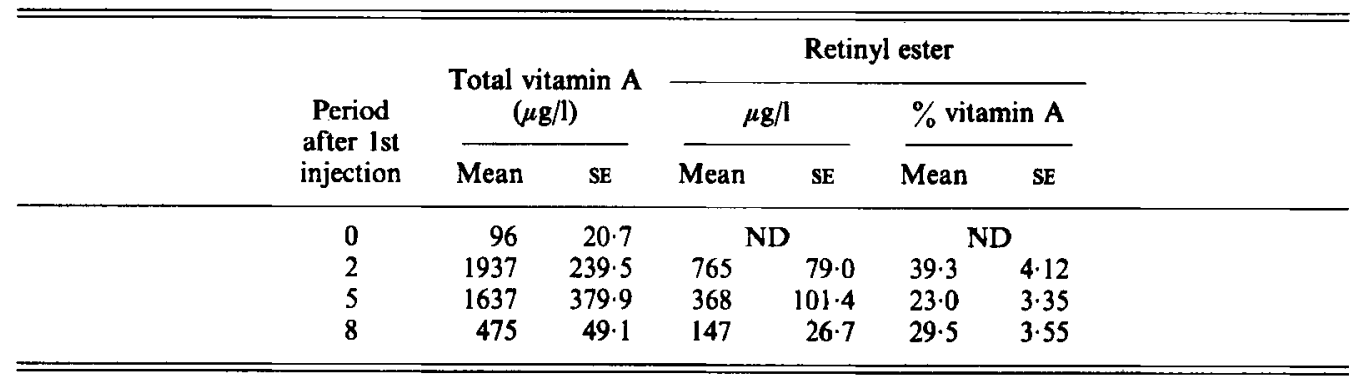

ND, not detectable.

- Daily injections of $30000 \mu \mathrm{g}$ aqueous vitamin A for first three days.

Before treatment, vitamin A was present in circulation mostly in the form of alcohol. The ester fraction accounted for approximately $10 \%$ of the vitamin in normal subjects while in malnourished children the levels were undetectable. After the administration of vitamin A, retinyl ester accounted for $20-30 \%$ of the vitamin (Table 2). There was no significant difference in this regard between the two groups of children. Those who received three doses of vitamin A showed a similar trend (Table 3).

\section{DISCUSSION}

Excessive doses of vitamin A taken orally or parenterally can result in acute toxicity. The dose that is required to produce toxicity is not known with certainty since there are wide individual variations. In some children, as little as $100000 \mu \mathrm{g}$ is sufficient (Marie \& See, 1954; Swaminathan et al. 1970), whereas in others considerably larger amounts are needed (Furman, 1973). Factors influencing vitamin A toxicity include age, state of nutrition, type of vitamin A preparation and route of administration. Present-day concern over safe use of vitamin A stems from the current practice of administration of massive doses of vitamin $A$ as an emergency or short-range approach to the eradication of nutritional blindness in children.

Acute vitamin A toxicity is characterized by anorexia, nausea, vomiting and irritability. Clinical diagnosis of toxicity is, however, difficult in an acutely ill malnourished child as he may have these symptoms even before vitamin $A$ is administered. Biochemical detection of toxicity is based on circulatory levels of vitamin A, particularly the ester fraction. In an adult consuming 1 million units of vitamin $A$ daily for a period of $25 \mathrm{~d}$, the serum level of the vitamin was reported to be as high as $13 \mathrm{mg} / 1$ (Hillman, 1956). Apparently, hypervitaminosis A occurs in vivo only when the intake of the vitamin overloads the liver's capacity to store excess in the form of retinyl esters. In this context, the relative level of retinol vs. retinyl ester assumes significance. Smith \& Goodman (1976) studied vitamin A transport in three subjects with hypervitaminosis $A$. In each of these patients the clinical toxicity was associated with increased concentration of total vitamin $\mathbf{A}$, and particularly of retinyl esters not bound to RBP.

In the present study, none of the children showed clinical signs of toxicity following vitamin A administration. Initial levels of serum vitamin A and RBP were significantly lower in malnourished children, an observation similar to that reported earlier (Smith et al. 1973; Reddy et al. 1979). Following the administration of vitamin $A$, the total vitamin as well 
as the retinyl ester fraction showed a significant increase in $24 \mathrm{~h}$ and tended to fall within $5 \mathrm{~d}$; this trend was observed in both normal and malnourished children. Even in those who received three doses of vitamin $A$, the retinyl ester fraction did not exceed $40 \%$, which is far below the level (65-67\%) reported by Smith \& Goodman (1976) in patients with vitamin A toxicity. These findings indicate that administration of massive doses of vitamin $A$ over a short period will not produce toxic effects even in malnourished children.

The best way to prevent vitamin A deficiency would be to provide small quantities of the vitamin daily in the diet. However, there are situations in developing countries where the diets do not meet vitamin $\mathrm{A}$ requirements and, therefore, resort has been made to intermittent massive dose intervention (WHO, 1976; Reddy et al. 1978). Malnourished children with corneal lesions are treated immediately on diagnosis with two or three massive doses of vitamin A (WHO, 1976; Reddy, 1978). Observations made here suggest that there is no risk of hypervitaminosis A with this treatment regimen. However, repeated doses of the vitamin are unnecessary since a single injection of $30000 \mu \mathrm{g}$ of aqueous vitamin A is effective in the treatment of severe xerophthalmia.

The authors thank M. Chandrasekharan and S. Chenniah for excellent technical assistance.

\section{REFERENCES}

Doumas, B. T., Watson, W. A. \& Biggs, H. B. (1971). Clinica chim. Acta 31, 87.

Furman, K. I. (1973). Am. J. clin. Nutr. 26, 575.

Hillman, R. W. (1956). Am. J. clin. Nutr. 4, 603.

Josephs, H. W. (1944). Am. J. Dis. Child. 67, 33.

Korner, W. F. \& Vollm, J. (1975). Int. J. Vit. Nutr. Res. 45, 361.

Mallia, A. K., Smith, J. E. \& Goodman, D. S. (1975). J. Lipid Res. 16, 180.

Mancini, G., Carbonara, A. O. \& Hermans, J. F. (1965). Int. J. Immunochem. 2, 235.

Marie, J. \& See, G. (1954). Am. J. Dis. Child. 87, 731.

Muenter, M. D., Perry, O. H. \& Ludwig, J. (1971). Am. J. Med. 50, 129.

Reddy, V. (1978). Ind. J. med. Res. 68 (suppl.), 26.

Reddy, V., Mohanram, M. \& Raghuramulu, N. (1978). Proc. int. Nutr. Congr Rio de Janeiro, p. 198.

Reddy, V., Mohanram, M. \& Raghuramulu, N. (1979). Acta Pediat. scand. 68, 65.

Rodahl, K. (1949). Nature, Lond. 164, 530.

Selvaraj, R. J. \& Susheela, T. P. (1970). Clinica chim. Acta. 27, 165.

Smith, F, R, \& Goodman, D. S. (1976). New Engl. J. Med. 294, 805.

Smith, F. R., Goodman, D. S., Arroyave, G. \& Viteri, F. (1973). Am. J. Clin. Nutr. 26, 982.

Swaminathan, M. C., Susheela, T. P. \& Thimmayamma, B. V. S. (1970). Am. J. clin. Nutr. 23, 119.

Vahlquist, A. (1974). Int. J. Vit. Nutr. Res. 44, 375.

WHO (1976). Tech. Rep. Ser. Wld Hith Org. 590, 50.

Wolbach, S. B. \& Bessey, O. A. (1942). Physiol. Rev. 22, 233. 